\title{
The Phenomenon of Urban Culture in Film Dendang Bantilang
}

\author{
Damar Tri Afrianto
}

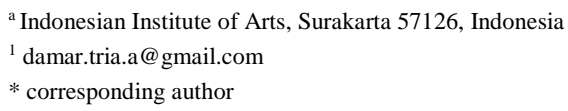

\section{ARTICLE INFO}

Article history

Received 2019-05-02

Revised 2019-05-25

Accepted 2019-05-26

\section{Keywords}

Film Dendang Bantilang

Pinisi

Urban Culture

Semiotic

\section{ABSTRACT}

Film titled Dendang Bantilang Director M. Ikhwan is one of the films that focus on cultural issues primarily in Bulukumba Regency. As a work of film, in addition to serving an aesthetic spectacle, but also showing the reality of the existence of a legend that is in the middle of a Pinisi of the current global era. This film does not only show the existence of pinisi at present, but show how urban culture contestation takes place in Bulukumba contextually. This is why the concern of this research leads to aspects of urban culture in the phenomenon in the film Dendang Bantilang. Through the method of semiotics Roland Barthes, this research found several realities behind their urban phenomenon in Bulukumba, among them; (1) the ceased of the chain of inheritance skills in the community of Bulukumba in making the pinisi ship as the main livelihood; (2) The fascination of work outside the village especially in Malaysia; and (3) The work of making Pinisi ship with a long process has an impact on the cost of wages that received late because wait for the completion of the shipbuilding. The results of the research showing the film Dendang Bantilang can be a reflection of contemplation that maintaining and harmonizing pinisi culture requires a strong and high awareness effort. Pinisi is the ancestral heritage of Indonesian culture both in form and knowledge, not to improve the flow of urban culture accompanied by the extinction of knowledge and skills about Pinisi.

This is an open access article under the CC-BY-SA license.

\section{Introduction}

Bulukumba District in South Sulawesi is an area that has high value-cultural heritage, Pinisi Ship. According to the local legend, this glorious ship that has been known and developed in Bulukumba District, was used by Sawerigading, a character in I La Galigo to sail to China to propose the Royal Princess but in the middle way back, the ship was sunken and stranded to three places, to Ara, Bira and Tanah Beru. These three places then considered inheriting expertise and knowledge about Pinisi in Bulukumba District. Although the source of the story is based on legend, that knowledge is the basis of history of Pinisi.

Ara, Bira and Tanah Beru villages became the center of pinisi ship building in Bulukumba Regency, even though the original pinisi model was difficult to find. One pinisi ship has a full length of 45 meters and the price was fantastic up to ten billions. Pinisi which is estimated to be used to sail the ancestors of the Bugis-Makassar tribe around the 16th century relied on nature, wind direction, astrology and other natural signs. The legendary pinisi has been transformed following the times, Pinisi must now be willing to become a commodity. Major countries such as France, Italy, the Netherlands, and several Asian countries now look at the toughness of the boat from this South Sulawesi. Those countries ordered pinisi in Indonesia for tourism needs, so the Pinisi form has been transformed into modified ones. 
The development of the Pinisi form in Bulukumba District should be the center of economic growth for the community, because ship orders from developed countries are increasing. But the situation is in actually inversely proportional, the high level of selling value of Pinisi is not followed by the number of people who have expert skills in making ships. Not many people and young generation in Bulukumba inherit Pinisi expertise, so young people usually migrate to work in the city or abroad to become TKI (Indonesian workers) in Malaysia. This can be seen from the data of the Central Bureau of Statistics (BPS) of Bulukumba, the absorption of labor in every sector of the economy in 2017 was recorded as many as 176.84 workers and the most dominant sector of employment was the agriculture sector which was around 54.38 percent (Bulukumba, 2017: 35) not in the maritime sector, especially in making pinisi as an icon of the area. Meanwhile the agricultural sector in the maritime zone is very limited, so eventually the community prefers to leave the area, and the implication is that urban culture is increasing.

The urban phenomenon in Bulukumba was presented fictionally in a film titled Dendang Bantilang, a work and director from Makassar, Muhhamad Ikhwan. Through fiction strategy, the urban situation and the reality of the legendary Pinisi ship are displayed dramatically. The power of film is not only for entertainment but film is an art of processing and intensifying our perception of reality (Bazin, 1967: 14-15). The film Dendang Bantilang presented narratives about the polemic that occurred in the development of Pinisi due to urban culture. In the film tells about a child named Mus who must bear the burden on culture to continue to preserve Pinisi over the mandate of his grandfather, while his father and his brother prefer to work to Malaysia, thus his mother and his grandfather died tragically before he became an adult.

This film does not only show the existence of Pinisi at present, but show how urban culture contestation takes place in Bulukumba contextually. This is why the attention of this study leads to film Dendang Bantilang especially on the aspect of urban cultural phenomena. Based on those considerations, the discussion and the analysis pay more attention to the scenes that have criteria on aspects of thought and action about the phenomenon of urban culture with the formulation of the problem of how the dramatic structure of the film Dendang Bantilang represents urban phenomena.

\section{Methods}

This study uses qualitative research with the aim of analyzing social behavior, especially social behavior in film Dendang Bantilang. Given stated that qualitative research to identify, analyze, and understand patterned behavior and social (Given, 2008: 706). The method that used in this study is analytical descriptive. This study attempts to identify the texts in film Dendang Bantilang which narratively represents the phenomenon of urban culture in Bulukumba. The texts were analyzed using the method of textual analysis and narrative analysis with semiotic theory of Roland Barthes. The textual analysis method provides a set of media texts so that the study reveals hidden constructs in media texts, especially film. Mckee explained that the method of textual analysis is the interpretations produced from the text. These interpretations are the process when we are encoding and decoding the signs in the unity of the text produced (McKee, 2003).

While the narrative analysis consists of two elements, story; a chronological order of all events presented and inferred by the text and plot; everything that the text explicitly present (what happen physical) (Nick Lacey, 2000). Regarding the sign interpretation process, the theory chosen is Roland Barthes's semiotics which reveals the meaning of the sign through the process of denotation and connotation.

Denotation in Roland Barthes's point of view is the first level whose meaning is closed. The denotation level produced explicit, direct, and definite meanings. Denotation is the truest meaning, which is mutually agreed upon socially, with reference to reality (McKee, 2003). Connotation, as a system, consists of a set of signifiers and signified, and the process that unites the first system into the second system (significance), an inventory of these three elements that we must consider first in each system. Signifiers are formed from signs (unification of signifier and signified) in denotation systems. Some denotation marks could be grouped together to form a single signifier, although the latter has a single signified connotation (Roland Barthes, 1983: 93). In a simpler meaning, connotation is a sign that the signifier has an openness meaning or implicit meaning, indirect and uncertain; it means that it is open to the possibility of new interpretation. This method of denotation 
and connotation patterns is the basis of the interpretation of the analysis in analyzing urban phenomena that are represented in Dendang Bantilang's film.

\section{Result and Discussion}

The urban phenomenon in Bulukumba in film Dendang Bantilang is presented through scattered symbols in the form of dialogues and scenes. Therefore, the semiotic method of Roland Barthes is directed at analyzing the scenes in which the urban phenomenon in Bulukumba is implied. The followings are the analysis process:

Scene that describes the beginning of the emergence symptoms of urban phenomena is in the scene 6 Figure 1. In this scene there is a dialogue between Mr. Mus and Ato' Cacca in the house.

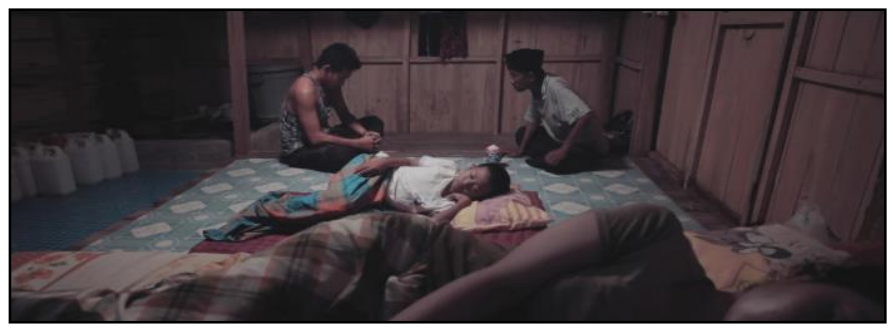

Fig. 1.Capture Scene 6. (00.12.04)

Dialogue scene between Mr. Mus (Left) and Ato' Cacca' (Right)

An explanation of the analysis of semiotics structure scene 6 is described in Table 1.

Table 1. Semiotics Structure Scene 6

\begin{tabular}{|c|c|c|}
\hline Denotation & Conotation & Meaning \\
\hline $\begin{array}{l}\text { ("I do not what to do, while the disease of Muli is } \\
\text { getting worse. Maybe it's time bring him to the hospital, } \\
\text { but I'm also afraid of bringing her to the hospital } \\
\text { because the hospital costs, expensive enough, want to } \\
\text { earn some money where, } \\
\text { While I don't have a job here") }\end{array}$ & $\begin{array}{l}\text { The submission of } \\
\text { character Mr. Mus } \\
\text { for not being able } \\
\text { to work in } \\
\text { Bulukumba after } \\
\text { his return from } \\
\text { Malaysia }\end{array}$ & $\begin{array}{l}\text { Limited job } \\
\text { vacancies in } \\
\text { Bulukumba }\end{array}$ \\
\hline
\end{tabular}

In scene 6 presents the despairing atmosphere of Mr. Mus who has the thought that in Bulukumba there is no work that matches his skill. The meaning in this scene is clarified in the next dialogue and can be seen in Table 2.

Table 2. Semiotics Structure Scene 6

\begin{tabular}{|c|c|c|}
\hline Denotation & Conotation & Meaning \\
\hline $\begin{array}{l}\text { (I don't have the expertise to make the boat, I haven't } \\
\text { even } \\
\text { never seen anyone working on the boat, how } \\
\text { can I work at bantilang. I also feel my place is not here, } \\
\text { therefore I plan to return to malaysia, there I can work } \\
\text { on a lot of things and send money here for health costs } \\
\text { Muli and cost my children school.) }\end{array}$ & $\begin{array}{l}\text { The figure of } \\
\text { Bapak Mus does } \\
\text { not have the skills } \\
\text { to make a ship } \\
\text { because the } \\
\text { interrupted } \\
\text { inheritance } \\
\text { process. The work } \\
\text { of making ships } \\
\text { requires much time } \\
\text { and cannot bring } \\
\text { money quickly }\end{array}$ & $\begin{array}{l}\text { The work of } \\
\text { making ships } \\
\text { (Pinisi) is not in } \\
\text { demand because of } \\
\text { the long } \\
\text { manufacturing } \\
\text { process and cannot } \\
\text { bring money } \\
\text { quickly. In } \\
\text { addition, the } \\
\text { inheritance process } \\
\text { to make ships was } \\
\text { interrupted, so the } \\
\text { generations of ship } \\
\text { makers and the } \\
\text { workers } \\
\text { diminished. }\end{array}$ \\
\hline
\end{tabular}

In this scene 6 is strongly describing the figure of Bapak Mus that is looking for work in his birthplace desperately. Apart from that he does not have many skills, in his birthplace he only 
provided shipbuilding work from his father-in-law's invitation to Ato' Cacca'. The analysis of Scene 6 opens the beginning of urban phenomena in Bulkumba, starting from the low level of community skills in making ships to the lack of providing alternative types of work. Bulukumba District with the image of the famous Pinisi ship turned out has cultural social problems about the breakdown of generations of pinisi makers. The younger generation of pinisi ship makers is decreasing in spite the number of pinisi ship orders from European countries is increasing.

In another scene, scene 11, in this film also conveys other problems related to Pinisi ship. Scene 11 through the dialogue of Ato' Cacca' Pinisi ship has changed, has become a cruise ship, so the people have forgotten to make the original Pinisi ship, the following is analysis of scene 11 described in Figure 2.

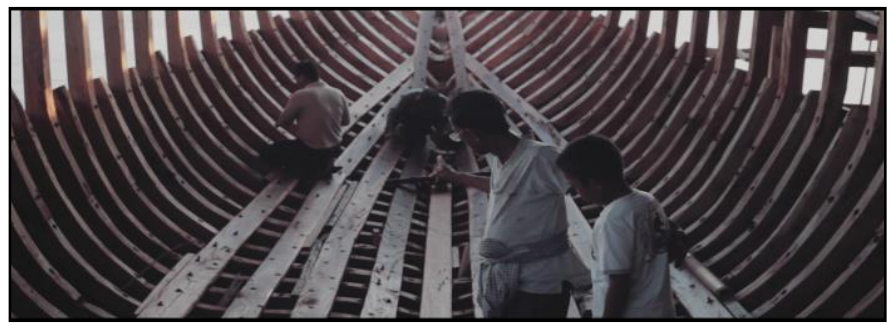

Fig. 2.Capture Scene 11. (00.18.34)

Dialogue scene Ato' Cacca' that is giving advice to his grandson

Explanation of the meaning of semiotics structure scene 11 can be seen in Table 3 .

Table 3. Semiotics Structure Scene 11

\begin{tabular}{|c|c|c|}
\hline Denotation & Conotation & Meaning \\
\hline $\begin{array}{l}\text { Ato' Cacca ' dialogue with his grandson Yusuf: } \\
\text { "That i'm working with my friends this is Pinisi ship, } \\
\text { this ship has been known since long time ago because } \\
\text { pinisi has acrossed the ocean until overseas, but most of } \\
\text { ships that made in here it's not like the ship that your } \\
\text { great grandfather made it anymore it's just the } \\
\text { foreigners order the ship based on their want it might } \\
\text { couse many people are here change into making a ship } \\
\text { with yacht model so, many people have forgetten the } \\
\text { way of making real pinisi." }\end{array}$ & $\begin{array}{l}\text { The pinisi ship has } \\
\text { transformed into a } \\
\text { cruise ship } \\
\text { according to the } \\
\text { demands from } \\
\text { developed } \\
\text { countries. } \\
\text { Modernism } \\
\text { demands all } \\
\text { aspects to be fast- } \\
\text { paced with } \\
\text { sophisticated } \\
\text { technology, so the } \\
\text { original pinisi } \\
\text { ships are } \\
\text { considered to be } \\
\text { lacking in such } \\
\text { moderation so now } \\
\text { it has turned into a } \\
\text { cruise ship. }\end{array}$ & $\begin{array}{l}\text { Pinisi ship has } \\
\text { changed now } \\
\text { following } \\
\text { modernity and } \\
\text { technology, the } \\
\text { impact of pinisi } \\
\text { itself has been gone } \\
\text { and turned into } \\
\text { cruise ships } \\
\text { according to orders } \\
\text { from European } \\
\text { countries. The } \\
\text { existence of the } \\
\text { original pinisi ship } \\
\text { was no longer } \\
\text { found, because } \\
\text { there were not } \\
\text { many local people } \\
\text { who inherited the } \\
\text { skills to make the } \\
\text { original pinisi ship, } \\
\text { they preferred to } \\
\text { migrate to get jobs } \\
\text { in cities and abroad } \\
\text { such as Malaysia }\end{array}$ \\
\hline
\end{tabular}

Scene 11 has a symbol that describes the situation where the original pinisi maker is more concerned, in the dialogue between Ato' Cacca' with his grandson.

"The people here are switching to make cruise ship models so that many people have forgotten

how to make the original pinisi, fortunately there are two friends of mine there (pointing to his two friends) who still be able to and want to make original pinisi ships."

In the dialogue above Ato' Cacca' explained that there were only two colleagues who be able to and would like to make original pinisi model ship. This condition is very worrying; the cause is nothing but the increasing urban culture. People are tempted by city life and moved abroad (Malaysia) which offers more diverse jobs. 
The scenes that so thickly illustrates the symptoms of urban phenomena in the film Dendang Bantilang is Scene 12. This scene jumped to 10 years later when Yus stepped into adolescence. Juvenile Yus was involved in a conversation with Ato' Cacca', in the dialogue Yus was already bored working to make a ship that did not come to an end, the work of making a ship was no longer his desire. Yus expressed his desire to meet his father in Malaysia who had never returned home since Yus was still a child. In Figure 3 is is the pattern of dialogue and analysis.

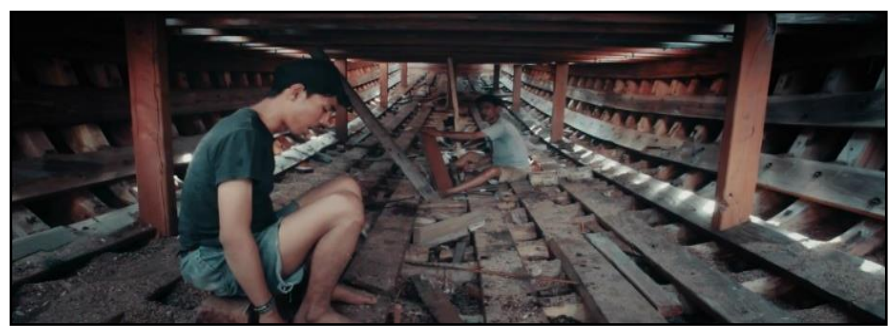

Fig. 3.Capture Scene 12. (00.21.25)

Dialogue scene between Yus and Ato' Cacca;

In Table 4 is the analysis of semiotics structure scene 12.

Table 4. Semiotics Structure Scene 12

\begin{tabular}{|c|c|c|}
\hline \multicolumn{2}{|l|}{ Dialogue } & \multirow[b]{2}{*}{ Meaning } \\
\hline Denotation & Conotation & \\
\hline $\begin{array}{l}\text { Yus said : "I am bored, grandpa !Everyday, I do the } \\
\text { same thing, the wood that never be finished to be cut, } \\
\text { refined, set and botted." } \\
\text { "What is not matter? it's really important grandpa ! it's } \\
\text { something important for me to know it, for eleven year, } \\
\text { I have been waiting for this answer, it's the time to look } \\
\text { for the answer, i feat also, i'm not suitable to work here, } \\
\text { at least, in Malaysia i can get better job to help to pay } \\
\text { Mus tuition" }\end{array}$ & $\begin{array}{l}\text { The conversation } \\
\text { between Ato' } \\
\text { Cacca' and Yus } \\
\text { connoted a } \\
\text { powerless Yus who } \\
\text { lives and works in } \\
\text { his own village as } \\
\text { a ship maker. Yus, } \\
\text { in addition to } \\
\text { reasoning to find } \\
\text { his father in } \\
\text { Malaysia who has } \\
\text { never returned } \\
\text { home, also want to } \\
\text { look for better } \\
\text { work with high } \\
\text { income than } \\
\text { making a ship that } \\
\text { has never been } \\
\text { finished. This } \\
\text { opens the } \\
\text { interpretation of } \\
\text { the connotation of } \\
\text { a picture or image } \\
\text { that working in } \\
\text { another country or } \\
\text { Malaysia in this } \\
\text { case is far better in } \\
\text { earning income }\end{array}$ & $\begin{array}{l}\text { Through Yus figure, } \\
\text { symbolic meaning that } \\
\text { arises is helplessness and } \\
\text { inability of local people to } \\
\text { live in their own village. } \\
\text { The village only provided a } \\
\text { place to work as a pinisi } \\
\text { ship maker, and some } \\
\text { people did not have the } \\
\text { skills and mental strength in } \\
\text { the shipbuilding process. In } \\
\text { addition to the shipbuilding } \\
\text { process that requires a long } \\
\text { time, working to make the } \\
\text { ship also does not promise a } \\
\text { fixed income and must wait } \\
\text { for the ship to finish than } \\
\text { the wages are paid. The } \\
\text { inability of the community } \\
\text { culminated in the desire to } \\
\text { leave their hometown to } \\
\text { work in neighboring } \\
\text { country or Malaysia which } \\
\text { offered faster job earning } \\
\text { income quickly. }\end{array}$ \\
\hline
\end{tabular}

Scene 12 is the climax structure of urban culture operating in the film Dendang Bantilang. Young Yus through his dialogue experienced a process of despair in his own village symbolically. Yus was depicted as a person who did not have strong mentality and low awareness of the inheritance of the pinisi ship as his ancestral cultural heritage, he gave up to the reality as a ship maker and rather chose to work in Malaysia, following his father. It was only his grandfather Ato' Cacca' and his younger brother Mus who still live in Bulukumba and remain loyal to the work of making pinisi ship. Meanwhile the section leading up to the conclusion, Ato' Cacca' died.

The process towards the conclusion of the film Dendang Bantilang is illustrated by the departure of young Yus to Malaysia represented by the visual frame of the ferry that can be seen in Figure 4 .

Damar Tri Afrianto (The Phenomenon of Urban Culture in Bulukumba, South Sulawesi, Indonesia in Film Dendang Bantilang) 
The ferry is not only a sign of the departure of Yusuf to Malaysia but also connoted urban regulation that continues to increase symbolically in Bulukumba. The ferry that brought Yusuf to Malaysia became a symbol of urban flow that could never be inevitable. Following are the symbol structure patterns.

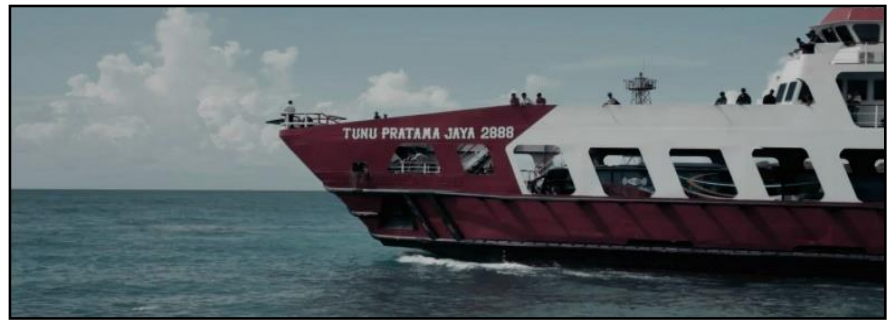

Fig. 4.Capture Scene 15. (00.24.16)

Visual frame of the departure of the ferry that took Yus to Malaysia;

The analysis of semiotics structure scene 15 can be seen in Table 5 .

Table 5. Semiotics Structure Scene 15

\begin{tabular}{|c|c|c|}
\hline Denotation & Conotation & Meaning \\
\hline $\begin{array}{l}\text { Frame depicting a ferry that carries passengers to } \\
\text { Malyasia }\end{array}$ & $\begin{array}{l}\text { The ferry connotes } \\
\text { increasing urban } \\
\text { flow symbolically. } \\
\text { The ferry gave a } \\
\text { picture of a man's } \\
\text { departure that } \\
\text { always leaves pain } \\
\text { for his family }\end{array}$ & $\begin{array}{l}\text { Through Yus The } \\
\text { ferry in one of the } \\
\text { frame film } \\
\text { Dendang Bantilang } \\
\text { showed the urban } \\
\text { charm is very } \\
\text { tempting. This is a } \\
\text { defeated form of } \\
\text { human in this case } \\
\text { is Yus in living life } \\
\text { as a pinisi maker in } \\
\text { his village. Yus } \\
\text { does not have the } \\
\text { mental and the } \\
\text { awareness to keep } \\
\text { the ancestral land } \\
\text { as a local people } \\
\text { that lived and grew } \\
\text { up in Bulukumba. } \\
\text { The work of } \\
\text { making ship } \\
\text { (Pinisi) is not in } \\
\text { demand because of } \\
\text { the long process } \\
\text { and does not bring } \\
\text { wages quickly. In } \\
\text { addition, the } \\
\text { process of } \\
\text { inheriting skills in } \\
\text { making ship } \\
\text { (pinisi) was ceased, } \\
\text { so the next } \\
\text { generation that } \\
\text { capable making the } \\
\text { ship and the } \\
\text { workers } \\
\text { diminished. }\end{array}$ \\
\hline
\end{tabular}

Urban flow in a region always leaves complex problems, both for the destination area and the abandoned area, the hometown. For urban destination areas causing population explosion, while for the villages left behind became a deficit area, this has implication for the wheels of an unstable economy. All of that causes an imbalance for regional ecosystem, therefore urban phenomena that continue to increase always not be expected. In Figure 5, this is illustrated in the conclusion of film Dendang Bantilang, in Scene 15 which depicts Mus, Yus's younger brother, running after the ship 
that Yus was riding toward to Malaysia. This scene explained symbolically the unexpected phenomena; Mus might fight alone in his village after his father left to Malaysia, followed by his older brother, while his mother and his grandfather died. The urban phenomena in this movie left pain clearly. Here is the explanation of scene 15 .

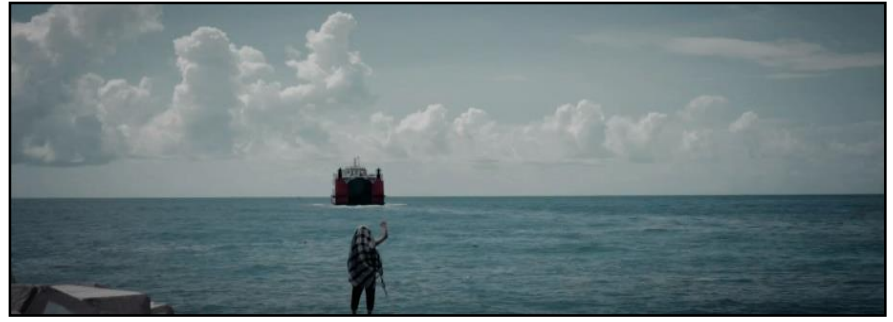

Fig. 5.Capture Scene 15. (00.24.32)

Scene of Mus who tried to chase the ship that carrying his brother

The analysis of semiotics structure scene 15 can be seen in Table 6 .

Table 6. Semiotics Structure Scene 15

\begin{tabular}{|c|c|c|}
\hline Denotation & Conotation & Meaning \\
\hline $\begin{array}{c}\text { Mus pursue andri Yus at the port but the ship has } \\
\text { departed }\end{array}$ & $\begin{array}{l}\text { Mus do not expect } \\
\text { Yus to go to } \\
\text { Malaysia. Mus } \\
\text { realizes that he is } \\
\text { still too young and } \\
\text { a children to be left } \\
\text { alone in village } \\
\text { with the burdens } \\
\text { that getting heavier }\end{array}$ & $\begin{array}{l}\text { Yus's departure to } \\
\text { Malaysia is a } \\
\text { practice form and } \\
\text { reflection of urban } \\
\text { phenomena, in this } \\
\text { case urban culture } \\
\text { is not always } \\
\text { expected because } \\
\text { the impact is } \\
\text { regression of the } \\
\text { area left behind. }\end{array}$ \\
\hline
\end{tabular}

\section{Conclusion}

Film Dendang Bantilang is a film that arises from reality that existed in Bulukumba and presented with creative dramatic fiction. On the other hand, film Dendang Bantilang does not only presented dramatic phenomena about the existence of current Pinisi ship, it is not a problem of a family that has been hit by an economic crisis. But through the analysis in this study we could conclude an understanding of urban flow problem that occurred in Bulukumba, South Sulawesi, Indonesia. This film is able to provide stimulants in the form of narrative and visual symbol that can be interpreted, so as to produce a process of symptoms against the background of urban cultural phenomena that occurred in Bulukumba. From the semiotic analysis using Roland Barthes's method it can be concluded that some meanings about urban phenomena.

Urban symptoms in the film Dendang Bantilang are based on (1) the ceased of the chain of inheritance skills in the community of Bulukumba in making the pinisi ship as the main livelihood. This could be seen in the figure of Bapak Mus and young Yus as the community representation that do not have skills to make pinisi ship, besides these two figures symbolize a lack of mental awareness of efforts to safeguard the ancestral heritage of the pinisi ship; (2) The fascination of work outside the village especially in Malaysia. The figures of Bapak Mus dan Yus, have perception that working outside village especially in Malaysia promises better life; (3) The work of making Pinisi ship with a long process has an impact on the cost of wages that received late because wait for the completion of the shipbuilding.

The result of premises above could be a recommendation for the local government in overcoming the increasing flow of urban culture in Bulukumba. The inheritance system for making pinisi ships must be upgraded, as well as considering the cost of wages that must be received by workers must be in accordance with the workload. It becomes ironic when the number of cruise ship customers increases, the workers decrease.

Film Dendang Bantilang could be a reflection of contemplation that maintaining and aligning pinisi culture requires strong and high awareness efforts. Pinisi is the ancestral heritage of

Damar Tri Afrianto (The Phenomenon of Urban Culture in Bulukumba, South Sulawesi, Indonesia in Film Dendang Bantilang) 
Indonesian culture both in form and knowledge, not to increase the flow of urban culture accompanied by the extinction of knowledge and skills about Pinisi.

\section{References}

Bazin, A. (1967). What is Cinema, selected and tarns Hugh Grey. Berkeley: University Of California Press.

Bulukumba, B. P. S. K. (2017). Indeks Pembangunan Manusia Kabupaten Bulukumba. Bulukumba.

Given, L. M. (2008). The Sage encyclopedia of qualitative research methods. Sage publications.

McKee, A. (2003). Textual analysis: A beginner's guide. Sage.

Nick Lacey. (2000). Narrative and Genre In film Studies. London: McMillan.

Roland Barthes. (1983). Mytologies. London: Metheun. 